\title{
Turning the Tide of School Segregation - India's Attempt to Make Its Private Schools Inclusive
}

\author{
Nalini Juneja \\ National University of Educational Planning and Administration, India
}

\begin{abstract}
Resistant to eradication, segregation in education is now no longer simply racially motivated but is increasingly being seen to be stimulated by the forces of commercialism in education. Recognizing the grave danger that such segregation poses to the rights of the child to education and to the larger fabric of society, the World Forum on Education at Incheon in 2015 focused on 'equitable and inclusive quality education' and reminded governments of their duty towards preserving the nature of education as a public good. Recognizing that turning the tide of segregation induced by increasing privatization is not simple, this paper presents the case of India where a recent federal law requires all private schools to include at least a quarter of their enrolment from among the poor. As seen in this paper, although not without its problems, the federal law was created by converting opportunities provided by existing legal commitments of private schools, the State in India is creating and enforcing new regulation in order to turn the tide of segregation.
\end{abstract}

\section{Introduction}

Political visions of an egalitarian society are not easily translated into reality. The veracity of this statement is evident in the experience of many countries including that of the USA which still struggles to combat the ill-effects of racial segregation. In many other countries which have not had a common school system, segregation in schooling tends to have a more socio economic basis, with schools for the elite and the rich, differing in form, content and outcomes from the schools available to children of parents with less access to better endowed schools or who cannot afford the fees charged by private providers of education. It is the experience of many countries, following the structural adjustments in education that came with globalization, liberalization and privatization in education, the entry of the market principles in management of schooling brought with them the changes which, no less than segregation, now confer increasingly disparate outcomes from educational experiences.
It has been observed that 'The last century has seen increasingly powerful efforts to transform the ideal of state run schools as democratizing civic institutions into the ideal of schools as a consumerist marketplace. In the increasing tendency worldwide to view education as a commodity, and in transforming schools 'from a public good to private privilege, from a social service to potentials for profit' [1] the role played by International trade agreements such as the 1994 General Agreement on Trade in Services (GATS) and earlier international trade agreements have often been highlighted.

Global Recognition of the need to combat the forces of commercialization in school education have led World Education Forum 2015, held at Incheon, Republic of Korea to adopt a new vision for its 'Education Agenda 2030' which focuses on 'Equitable and inclusive quality education' for all.

The Incheon Declaration reaffirmed that 'education is a public good, a fundamental human right and a basis for guaranteeing the realization of other rights'. The declaration committed itself to the provision of " 12 years of free, publicly funded, equitable quality primary and secondary education". There is no doubt that this global declaration of intent which aims to remind states that education is a public good, and that they need to commit themselves to providing at least 12 years of publically funded education (which also needs to meet the criterion of equitability) can hardly be enough to turn the tide of commercialization in education. Nevertheless, its importance lies in the fact that it sets a normative agenda.

Such a normative agenda becomes a standard bearer and a focal point behind which local, individual efforts combating the forces of marketisation, discrimination and segregation may rally around and draw strength from. One such effort is that of India's 'Right of the Child to Free and Compulsory Education Act, 2009' - or more specifically, its clause 12.i.c which tries valiantly to reverse the trend of increasingly stratified educational provisioning in India by placing a responsibility upon private schools to admit at least a quarter of their yearly admission from among economically weaker sections who would not have normally have afforded education in a fee charging school. 
This paper in Section 1 provides a brief introduction to this clause in India's 'Right of the Child to Free and Compulsory Education Act, 2009' which is attempting to combat deeply entrenched notions of privileged sections of society and their rights to a school of fitting status. However, mindful that such a legislative attempt should be aware of the resilience of tendencies towards segregation this paper touches upon them in Section II.

Reverting to the larger issue of segregation, Section III reminds the reader that the fissiparous tendencies of privatization and commercialization in school education need to be uprooted with determination. Not only do they violate of the rights of children in developing countries, but through their more insidious forms, they threaten even the developed world. This section takes the opportunity to expand on the forms that commercialization takes in education, and the manner in which they pose a threat to our commitments to democracy and education. Having established the threats posed worldwide by segregation and discrimination in education, this paper returns in Section IV to the Clause in the Indian Federal law and traces the process by which this legal obligation was incorporated into India's Historic Compulsory Education Act.

Predictably, the experience of implementation of this clause in private schools continues to be far from smooth, and this section goes on to describe some the problems currently being experienced by the economically weak families who have put their children into elite private schools on the basis of this provision. Given the resilience of segregation wherever attempts have been made to wipe it out, this paper in Section $\mathrm{V}$ ponders the question of whether or not the tide of segregation and commercialization can yet be turned and whether the divide between schools of the rich and of the poor, may yet be breached. Finally the paper discusses and reiterates the recommendations of the Special Rapporteur on the Right to Education for regulation of private schools in order to contain commercialism.

\section{The Clause}

In order to strike a blow for desegregation in the highly stratified hierarchy of schools operating in India, a legal clause in the first ever, federal law in school education mandated inclusion of children from economically weaker sections into all private schools. India, which has never adopted common schooling, nor ever required its schools to be equal, has, as may be therefore expected, a highly segregated and stratified schooling system. In part due the poor funding and management of government schools, private schools in India, of whatever size and quality, tend to enjoy 'brand advantage' in terms of projecting an image of superior quality. Admission in a private school, (as opposed to the default option of attending a government school) is generally perceived as a marker of status. Also, the majority of these schools purport to teach in English, the business language, and which since the days of the British colonial rule in India, has been the language of power. Deterred on the one hand, by the poor appearance and functioning of government schools, and lured on the other by the promise of a better future for their 'English educated' children, parents see it as their duty and take pride in the fact that they can afford to send their children to a private school. Private schools too, have come up in large numbers to suit every pocket. Initially restricted to a few elite schools attended by the rich, the increasing numbers of low fee private schools testifies to popular demand across the socio economic spectrum. Private school enrolment in India representing over a third of the country's school going population, is arguably one the largest system of private schools in the world with almost forty per cent of all enrolments nationwide being in private recognized and unrecognized schools [2].

Schools of varied descriptions and affordability have sprung up to cater to demand, as brands to a niche market. Therefore, within each school the clientele is usually restricted to a narrow socioeconomic band, partly due to differential fees, but also because private schools (until recently outlawed) could screen and select pupils, resulting in a segregated situation not unlike apartheid, based on economic criteria. Thus in India large socio economic variation may be found among those attending government and those in private schools, and between schools themselves large disparities are evident in quality and infrastructure [3].

In order to break the image of private schools being seen only as enclaves of the privileged and to reinforce the legal position that schools in India cannot be seen as business, but can only be set up to serve a public purpose, India's first National Act on free and compulsory education mandated that all private schools shall hence forth:

"...admit in class I, to the extent of at least
twenty-five per cent of the strength of that
class, children belonging to weaker section
and disadvantaged group in the
neighborhood and provide free and
compulsory elementary education till its
completion" - Clause 12.i.c Right of Children
to Free and compulsory Education Act 2009 .

This clause mandating inclusion of the poor in all private schools now applies to almost 50,000 schools and seeks to change the 'exclusive' 
character of their social composition. According to one estimate the implementation of this clause could make available about one million seats each year for the inclusion of children from disadvantaged and weaker sections into fee charging schools that would not normally have given them access. This clause, like education itself, in a context such as India's is at once an act of faith and of social engineering. But at the government has taken to care to explain, in the rationale for each of the clauses that it is not quickfix social engineering. In view of the fact that children take time to socialize and teachers take time to develop new attitudes and pedagogic skills, the Act provides for admission of disadvantaged and poor children at the entry level, covering pre-school and Class I. With these children moving up, and a new cohort of children entering pre-school and Class I in each successive year, the school will gradually have a more diverse population spread across all classes. Progression at this pace will allow children the opportunity to grow up together and create bonds: bonds that can survive social walls.

\section{Resilience of Segregation in Education}

The clause mandating inclusion of the poor into otherwise in accessible fee charging private schools is an attempt not unlike that of Brown [4] seeking to prevent segregation and the discrimination from wrecking the social fabric of a democratic society. Whereas in India, the basis of segregation is economic, in the United States, it was initially racial. Nevertheless the advent of privatization and commercialization of education in the USA, and its accentuation and differentiation in India, in both countries contradicts their credo of democracy and espoused values of equality of opportunities, and also threatens the right to education.

Both the Brown judgment and the Indian mandate are historical and ground breaking, but the comparisons are unlikely to end there. Desegregation in education even in the USA has been slow, and not yet successful despite the passage of more than half a century.

This is evident in the testimony in recent literature [5], [6] to the reemergence of segregation in the USA. Intervention by law and the highest courts cannot it seems guarantee compliance. Despite the force of the law, desegregation efforts met with resistance in the USA, particularly in southern states, for according to Dorsey [5] 'the Brown decisions brought little movement but instead generated much resistance from school districts', to the extent, that In 1963, before the passage of the Civil Rights Act of 1964, only $1 \%$ of Black students in the South attended schools with a predominantly White student population.

Although the Supreme Court established monitoring mechanisms for a desegregation plan framework for school districts known as the 'Green Factors' after the case of Green v. County School Board of New Kent County (1968), the monitoring of these six factors viz. (a) the composition of the student body, (b) faculty, (c) staff, (d) the transportation system, (e) extracurricular activities, and (f) facilities, worked to raise the percentage of African American students attending majority White schools to a peak of $43 \%$ by 1988 . This figure soon fell to $30 \%$ in the school year 2000-2001. In that year, Black and Latino students were on average, attending schools that were more than 50\% minority, White students on the other hand, tended to be in schools that were $79 \%$ White [5].

This continuation of discrimination and the resilience of supporting belief systems have so far belied Gunnar Myrdal's optimism of converting the vicious cycle of discrimination described in $A n$ American Dilemma [7] into a virtuous cycle.

\section{Privatization, Commercialization as Threats to Right to Education}

Segregated schools and inequalities in education need to be viewed not only as violating the underlying principles of democracy but also from the perspective that they violate the Rights of the Children to education 'on the basis of equal opportunity' as enunciated in 1989 in Article 28 of the UN Convention on Rights of the Child. Commoditization, commercialization, and inequalities in education also violate a number of clauses in the International Covenant on Economic, Social and Cultural Rights.

In most countries which have already universalized education, education had historically been a public concern. However, in recent decades, in moving away from the principles of production of education as a public good and a non-profit activity; the provision of which should be considered as one of the primary responsibilities of the state; states are violating norms of non -discrimination, equality of opportunity and social justice in education according to Kishore Singh, UN Special Rapporteur on Right to Education [8].

Examples of this are not uncommon globally, but abound in developing countries. In special reference to the case of Chile, already an unequal society with concomitant inequalities in the education sector but where decades of rule under dictatorship had led to the proliferation of market friendly innovations such as school voucher programs it has been averred [9] that privatization has lead to high levels of school segregation and stratification, differences in performance between socio-economically diverse students, and inequitable opportunities in terms of access to higher education, and that 'the education market actually has an intensifying effect on the existing socio-economic gap'. 
Similarly in India, where too an already stratified society exists alongside a history of educational provisioning though secondary schools managed by private trusts, it has been noted [10] that, 'in 1991, the Indian state launched far-reaching reforms to liberalize, deregulate, and privatize the public sector, including social sectors such as health and Education', with the result that many state governments 'divested themselves from government schools, shrinking the size of the sector and adversely impacting quality'. She further quotes studies to show that 'the government's reduced priority toward providing sufficient resources to elementary education has indirectly increased the privatization of schools at elementary level'. Starved of government funds, schools suffered neglect, thereby 'creating a mass exodus of working poor and middle class from public schools and leaving the poorest and most vulnerable behind' (p. 9). The increasing segregation in access to education in India is well documented [11], but now with newer forms of privatization in the education sector in India, 'Among developing countries', it is noticed [10] that 'India is almost always underscored as an education market ripe with potential and profits'

This only reiterates the point made earlier that commercialism pushes schools away from being centers of learning serving the public good and toward becoming profit centers for private interests. Its causes schools to be perceived 'not only as markets for vendors but as venues for advertising and corporate public relations and as commodities to be bought and sold' [1].

The negative impact of segregation has been well documented in social science research in the USA as leading to poor achievement levels, larger class sizes, fewer teachers, low quality course offerings and lower graduation rates. Integrated schools, on the other hand, were seen by research findings as benefiting all students of all races and ethnicities socially, emotionally, and academically. Mixed classrooms have typically resulted in higher standardized test scores, and better track placements in high schools, and are positively correlated with 'positive outcomes with regard to living, working, and interacting with people of different race and ethnicities than students who attended segregated schools' [5].

The emergence of differentiation in education, leading eventually to differential outcomes, can begin innocuously as 'reforms'. For example in the case of Sweden, [11] the emergence of the 'Market oriented Teacher' in Swedish schools came with governance reforms driven by the principles of New Public Management. 'Put into political practice, marketisation in essence constitutes a complex phenomenon, involving many different facets. The introduction of school competition, voucher systems, customer choice, and private companies in the production of education are some key expressions of marketisation in public education'

It has been found useful [1] to classify commercialism in schools as taking three basic forms- Selling to schools; Selling in schools; and Selling of schools. Describing 'Selling to schools' as 'vending', it has been considered as uncontroversial and long standing the practice of private vendors selling to schools the routine supplies needed by them such as stationery, furniture, cleaning supplies etc. Selling in schools is also a long standing practice according to Molnar, but can be controversial for 'It has the potential to influence thinking and values in that such commercial activity offers 'access to students in an unprecedented diversity of ways' for 'It encompasses the use of schools by corporations to sell products or services, promote their points of view or address public relations or political problems.

The pervasiveness of schoolhouse commercialism carries with it the potential for distorting and biasing the lessons children are taught. For example, curriculum materials sponsored by corporate interests may offer self-serving information about controversial subjects.' [1]

Private schools with their limitations of in house personnel and technical resources can be especially susceptible to offers of sponsorship of sports events or of free teaching learning resources in subjects as innocuous as science, but which carry with them hidden messages conveying the 'goodness' of a product when it is introduced within school premises and appears to be endorsed by it - 'probably the result of both the increase in marketing to children in general and the vulnerability of schools' [1] (p. 623).

In an effort to combat such commercialism, an eight point method of recognizing and tracking of commercialism indirectly through media references looks out for:

1. Corporate sponsorship of school programs and activities.

2. Exclusive agreements giving marketers exclusive rights to sell a product or a service on school or district grounds.

3. Incentive programs using commercial products or services as rewards for achieving academic goals.

4. Appropriation of space, including the selling of naming rights to businesses or advertising space on school premises or property.

5. Corporately sponsored educational materials, including lesson plans and curricular materials directly sponsored by corporations. 
6. Electronic marketing that, through electronic media, including radio, television and the Internet, targets students through schools.

7. Privatization, including private management of public schools, public charter schools and private, for-profit school involvement in voucher programs.

8. Fund-raising relationships between schools or school-affiliated volunteer groups, such as parent-teacher associations, and businesses to sell products or services in order to raise money for schools.

\section{India's Desegregation Effort through Federal Law: Obstacles and Hopes}

As stated earlier, India, never having had a common schooling system, could be said to have 'always' had private schools and therefore a system of segregated education for those who could afford fees as opposed to the default option of either no education or access, when it became available, to poorly funded state provided schools. Historically, education in India was the preserve of a few privileged males of certain high born castes. A somewhat formalized system of specialized education in particular skills by apprenticeship and residence with a proficient guru or 'ustaad' also existed. During British colonial rule, the government by and large restricted itself to the provision of primary education in areas under municipal corporations, and had left post- primary education since the 1880 s to be provided by 'local native management' [12]. In course of time, these private schools providing upper primary and secondary schooling were granted aid from the government. In response to the growing demand for education, more fee charging schools, not necessarily aided, sprang up to provide education both in vernacular languages and in English

The perceptual frame of education prevailing at the time saw education as welfare, rather than a right of the child and a duty of the state. Historically in India, in the absence of adequate provisioning by government, there was a dependence on private schools, an acceptance of duality in schooling, and little use in general for democratic notions of universal education and common schooling.

In such a context, the mandate of a federal law in 2009 placing an obligation on private fee charging schools, requiring them to transform themselves from the 'exclusive' preserves of the privileged that they were, into egalitarian havens welcoming the forced inclusion of children from low socio economic groups was destined to meet with opposition.

Predictably, the clause mandating inclusion and the entire Act that carried this clause was met with stiff opposition. It was challenged in the Supreme Court of India. Fortunately in the era of acceptance of education as a right not only under international law, but as a fundamental right in the Constitution of India since 2002, the validity of both the clause and the law was upheld in 2012 by the Supreme Court. Exemptions were however granted to unaided minority-managed schools as well as residential schools. These schools were absolved of responsibility of admitting $25 \%$ of the poor. Later, in another case, all minority schools were also absolved of implementing the RTE Act.

This clause might have met with greater opposition and lesser support from the judiciary had the idea of inclusion of inclusion of the poor in private schools not already been a legal obligation although only on paper- for a vast majority of elite private schools who now occupied many acres of now prime real estate in the centre of cities. The land on which the schools stood had been granted to them free, but with the condition that they would also provide free education to the economically weaker sections as public service to those who would not be able to afford their fees.

It is this obligation, placed on the land contracts of these schools that paved the way both for the clause in the Federal Act and its defence by the Supreme Court half a century later.

Royal bequest of lands at the pleasure of the emperor, had been a tradition (called 'Nazul') in India since era of Mughal rule in India and was continued under the British Raj through rules known as the 'Nazul Land Rules'. After the Independence of India, a chapter in a land policy document of the 1950 s, termed 'the social objectives of land policy' advocated the use of the lands in order to serve the social objectives of the Constitution of India [13]. Accordingly, the first Master Plan of Delhi (1962), which became the Model for city master plans all over the country incorporated in its provisions for allotment of government land to private schools which were being set up to carry some of the children who might otherwise have gone to government schools. In lieu of the land allotted to them, the schools were bound by a clause such as given below:

'The -(society)------ shall ensure
that the percentage of free ship from
tuition fee as laid down under rules by
the Delhi Administration from time to
time is strictly complied. They will
ensure admission to the students
belonging to the weaker sections to the
extent of $25 \%$ and grant free ship to
them

Private schools eager to take advantage of this largesse of the government in Prime locations of 
major cities, came forward readily and the number of private schools increased manifold in each decade [14] (see Figure 1).

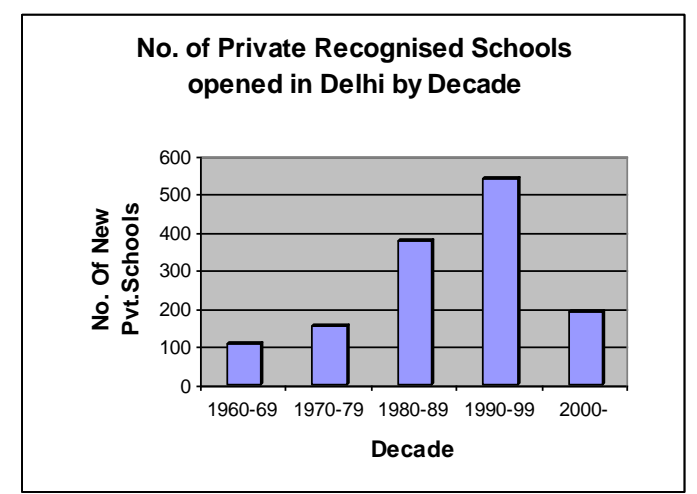

Figure 1: Number of Private Schools Opened In Delhi by Decade

It might be safe to say, that few private schools might have been able to afford to buy land in these cities at the prevailing rates. For example, a plot of 1.7 acres was granted by the Delhi Development Authority to a school in a prime location for an amount comparable to the registration fees being charged in the same year for a two bedroom apartment by the same development authority.

An example of the advantage gained by these schools may be gauged by the example of a a society which was allotted 1.7 acres of land in 1983 to set up a school in a very posh area of New Delhi, for a price equivalent to that being charged by the land development agency simply to file an application for a small two bedroom apartment. Similarly, another society received almost 4 acres of prime land in the city for less than the value of Rs. $20,000 /$ - or less than 300 dollars today. In contrast, recently about 2 acres was bought for a school in an outlying area of Delhi at an auction ten years ago, for the sum of almost Rs. 200 million.

\subsection{Obligations disregarded by private schools}

The obligations of private schools were largely disregarded by them, as was revealed by a case filed before the Delhi High Court. Thereafter the Comptroller and Auditor General of India also decided to conduct its own investigation into the matter of compliance of the schools, with their legal obligations towards the poor. The Comptroller and Auditor General's Report [15] for the period 199091/2003-4, found that about 381 societies were allotted land for schools. Of these they scrutinized only a quarter of the cases. Of the 90 cases they looked at, the CAG of India found that more than half of the societies allotted land were 'non functional'. Another 27 of them did not have the funds to even pay the concessional amount for the land. Out of 90 , only 24 of the societies that received land had set up schools that were functioning. Of these 24, 19 were not offering any free ship at all. Of the five that were, offering some free ship - none were giving 25 Percent as per their land lease clause obligation.

The same year, the Dept. of Education Delhi, also did an independent scrutiny of 109 cases of schools. Of these, 69 cases $(63 \%)$ of the schools were offering no free ships. In the remaining 40 schools the free ship offered ranged from 1 to $24 \%$.

\subsection{Acts of Omission by Government}

While on the one hand, a government decades ago had put in place a law to ensure the social objectives of the Constitution of a new nation was supported by a land policy that sought to ensure inclusive education, other governments down the road ensured equally that that these plans did not come to fruition. For, it came to light form the same CAG report of 2005 that no mechanism existed for identifying breaches of allotment, and therefore no remedial action could take place.

Nor did schools subscribe whole heartedly to the ideology of service to the nation in the intentions behind setting them up. A Study [16] on self reports of 80 schools (All India), found for example that the memorandum of association of these schools (MOAs) do not mention any charitable purpose; and on the contrary, for every Rs. 100/- worth of concession received, schools spend Rs.27 on socially useful work, while $59 \%$ of schools did not spend money on scholarships.

Such damning revelations about private schools, which had up to now enjoyed good press and were perceived as offering 'good education' coming upon the filing of the Social Jurist case came just in time to influence the development of the legislation following the amendment of the Constitution to make education a fundamental right. Through a process documented in detail elsewhere, [17] the clause mandating the social obligation of each private school to become a socially inclusive school found its way in to the India's historical legislation on free and compulsory education.

There remains no doubt that the RTE 2009 clause for reservation of 25 per cent seats in all private schools, was received enthusiastically by parents from economically weaker sections. This was evident in the huge rush for private schools among the DG and EWS categories. In the 2014-15 admissions in Delhi, 164,575 applications were received for 22616 reserved seats in 1186 schools when compared to 253,675 applications received for open 81198 seats in the same schools.

'State of the Nation: RTE Section 12 (1)(c )' on implementation in 2013-14, a study report by 
'Centre Square Foundation', an NGO, The Indian Institute of Management, Ahmadabad, Accountability Initiatives, an NGO and Vidhi Legal Centre for Legal Policy reviewed the current systems and mechanisms for implementation on five dimensions - i) clarity in defining eligibility and documentation required, ii) process of information outreach/awareness, iii)selection process, iv)transparency in reimbursement provisions and reimbursement process, v) grievance mechanism and monitoring. The report found that systems and procedures are not in place and hence implementation gaps are enormous.

A group of civil society organizations (such as The Centre for Social Equity and Inclusion (CSEI) along with member organizations of Section 12 Watch Group and Delhi RTE Forum) which have been tracking implementation of Section 12 (1) (c) since 2011-12, conducted a Public Hearing in December 2015, in which 28 cases where parents faced barriers and constraints in availing this provision was documented across different districts. The different implementation gaps are summarized below:

a) Additional Costs in School and Indebtedness. This was the most prevalent problem for most parents who found that additional costs for school supplies, uniforms extra tuition after school etc. cost more than they could afford and were forced into debt in order to keep the children in such schools. Parents also fear that they may not be able to meet the school costs and their children may have to drop out from school at a later time.

\section{b) Distance Criteria and Lack of Access to Private Schools.}

While private schools are allowed to draw their children in the general category from a distance of 6 -8 kilometers, the provisions of the Act and guidelines are narrowly interpreted to deny admission to economically weaker children whose habitations are beyond a kilometer from the school. Thus the distance criteria become a passive exclusion factor for large numbers of children.

c) Not complying with the Act in the admission of children with disabilities.

Children with disabilities are given special provision under the Act and its rules, but the schools use excuses discouraging parents of children with disabilities from seeking admission saying that the school did not have the necessary support mechanism to teach the child.

\section{d) Lack of Transparency in the Admission} Process.

The admission procedure mandates that the lottery system be followed. Parents are to be informed to be present for the lottery which will be overseen by a person designated by the department and the procedure video-recorded. However, this rule was followed more in its exception.

\section{e) Disrespect and Discrimination towards} Parents.

Parents report that discrimination and threats from the schools whose attitude tends to be that 'we are obliging you by having your children in the school you need to be thankful -what complaints can you have'. In some cases, they were also told that their children may face discrimination, being put in a corner if they did not comply with the demands of the school.

\section{f) Ineffective Grievance Redress.}

Parents from the DG and EWS communities have inherent difficulties in accessing the GR mechanism in terms of lack of social contact, lack of information, inability to follow up on complaints, time taken and support needed to use GR. Parents find it difficult to track the status of their on-line complaint and hence lose the opportunity to sort out the matter. Despite many complaints submitted to the department and on-line, the issues were not solved.

g) Time, Cost and Hurdles in applying to multiple schools in the local area.

Often parents are very keen to have their children admitted to private schools, and therefore they apply to all possible schools near them. They spend more than a month in tracking the application process. In addition, they have to get many certificates $-\mathrm{SC} / \mathrm{ST}$ certificate, disability certificate, address proof, income certificate etc. Each of these certificates demand time and even costly.

\section{h) Not given entitlements.}

In the private schools, parents have to pay greater costs but have no access to any financial assistance from the state.

i) Schools neglect the guidelines and circulars from the department regarding the provision. Neglect and violation of the guidelines in putting notice boards outside the schools, unwillingness to accept application forms from the parents, unwillingness to clarify norms to the parents are widely prevalent.

\section{j) Multiple Violations.}

Multiple factors often act together to create an extremely complex negative environment for the parents and children. On the other side the absence of any engagement with the private schools and teachers on understanding the issues of the disadvantaged children, lack of any pro-active 
equity support mechanism in the school, the absence of any creative interface to build inclusion actions in the school act as barriers too.

The Indian attempt towards desegregation can be seen to at least puncture, if not dissolve the compartmentalization of the schools for the rich from the schools of the poor. In this effort India relied upon old legislation and used it to influence new national laws. The implementation of this law, although patchy and a work in progress, is at least causing a change in the discourse regarding the types of schools accessible to the poor. When one among them, given good teaching learning conditions, succeeds, it no doubt challenges deficiency theories and raises questions about the disparities among educational provisioning.

\section{Can the Tide of Segregation be turned?}

Although court judgments such as Brown have spelled a blow to segregation, the law could well provide protection for the rights of the children to education without discrimination. The Special Rapporteur, Right to Education reminded the International community that a number of court rulings worldwide have established that private providers of education are accountable to the State and to the public [8]. Quoting in his address to the UN human Rights Council, legal precedents in Nepal, South Africa, India, Columbia, and the United States, he stated that 'Public accountability of privatized schools and availability of remedies and recourse from their decisions should specifically be provided for by law.' (p.16). Regulations so framed should be, according to Singh, 'prescriptive, prohibitory and punitive' (p. 18).

Prescriptive regulations should establish clear conditions under which private operators may be permitted to operate. Prohibitive regulations are required in order to make illegal discriminatory practices, and any activities that deviate from the principles of provision of education as a social responsibility and a duty of the state. For profit school education should clearly be banned. Punitive regulations ensure compliance. Unless strong deterrents are spelled out, and strong action actually carried out against those who engaging in social injustice, fraud and corruption in education, regulations might have no meaning. Most of all there is need for good understanding and awareness of the harm that discriminatory and segregation can wield on the social fabric.

\section{Conclusion}

This paper, describes primarily the experience of implementation of a recent law in India which strikes a blow, albeit a soft one, against school segregation. Even as it does so, it raises issues related to newer sources of segregation among schools such as privatization and commercialization. It raises again the issue of education as a public good, an issue which is topical once again following the Incheon Declaration in 2015.

It is ironic, that private schools in India which were supposed to be set up only for providing a public service appear to have forgotten that noble aim, and due to acts of omission of the government have, over the years have become accustomed over the course of fifty years to running their schools as they would. When suddenly such schools are reminded about their duty, they have acted to protect what they see as their privileges.

Parents from the weaker sections are on the other hand, becoming aware of the difference between the schools that the state provides, and the schools that they can get access to. After a few more years, when such parents will form a sizable number in the community of parents, they might become bold enough and unite across schools to claim more facilities and better treatment. Schools too might be forced to change and acknowledge that they need to become more sensitive to the economic diversity in the classroom.

This clause has attracted the attracted the attention of the world, and a large numbers of nongovernmental organizations have devoted themselves to ensuring that seats for the weaker sections are filled, that parents are assisted to enter and sustain their wards in such schools. Problems of the type mentioned in this paper, had probably played themselves out in USA when the first generation of black children were admitted by law into formerly segregated schools. This paper which spoke of India's experience of the use of law to fight school segregation also highlights the importance of regulatory frameworks centered on education as a public good.

A renewed discourse is gaining ground supporting the protection of school education from commercialization. The Incheon Declaration and its framework for implementation have reiterated the role of governments in protecting the rights of the child and for providing 12 years of free publicly funded education. The Un Special Rapporteur for Right to Education has devoted more than one of his reports to the related issues of Commercialization, Discrimination, and Privatization of education. Although powerful efforts have attempted, and greatly succeeded worldwide to convert schools into educational marketplaces, this paper, focusing on the use of the law to fight against school segregation suggests that there may yet be hope converting the vicious cycle of discrimination described in Myrdal's An American Dilemma into a virtuous cycle. 


\section{References}

[1] Alex Molnar (2006), The Commercial Transformation Of Public Education, Journal of Education Policy, 21:5, 621-640, DOI: 10.1080/02680930600866231. http://dx.doi.org/10.1080/02680930600866231 (25 July 2016)

[2] NUEPA (2013, December) dise.in/flash.htm http://schoolreportcards.in/DISEUsers/Login.aspx?Return Url=\%2fDISEUsers \%2fdownload.aspx \%3ffile\%3dFlash $\% 2520$ Statistics $\% 25202012-13$.pdf\&file=Flash $\% 20$ Statistics\%202012-13.pdf (6, January, 2014)

[3] Juneja, N. (2010). Access to what? Acess, diversity and particpation in India's Schools.http://www.create* rpc.org/publications/ptas/ (6 March 2016)

[4] Brown v Board of Education, 1954. (n.d.). Retrieved March 27th, 2013, from Street law,Inc: www. streetlaw.org/en/landmark/cases/brown_board_of_educati on

[5] Dorsey, D.N.T. (2013). Segregation 2.0: The new generation of school segregation in the $21 \mathrm{st}$ century. Education and Urban Society,00131245134 86287.

[6] Williams, S. M., \& Houck, E. A. (2013). The life and death of desegregation policy in Wake County public school system and Charlotte-Mecklenburgschools.

Education and Urban Society, 45(5), 571-588.

[7] Myrdal, Gunnar. (1944). An American Dilemma: The Negro Problem and Modern Democracy. New York: Pantheon Books, 1972.

[8] Singh, Kishore (2015). Protecting the right to education against commercialization. Report of the Special Rapporteur on the Right to Education to the United Nations General Assembly Human Rights Council, $29^{\text {th }}$ Session.

[9] Verger, Antoni (2014) Decommodifying Education in Chile.www.educationincrisis.net/blog/item/1122-decom modifying-education-in-chile?-bachelets-reforms-in-theface-of-persistent-educational-inequalities (28 July, 2016).

[10] Kamat, S., \& Spreen, C. A. (2016). Profiting from the Poor:The Emergence of Multinational Edu-Businesses in Hyderabad, India. https://download.ei-ie.org/Docs/ WebDepot/ei-ie_edu_privatisation_final_corrected.pdf (30 July 2016).

[11] Fredriksson, A. (2009). On the consequences of the marketisation of public education in Sweden: For-profit charter schools and the emergence of the 'market-oriented teacher'. European Educational Research Journal, 8(2), 299-310.

[12] Juneja, Nalini (2007) Private Management and Public Responsibility for Education of the Poor: Concerns raised by the 'Blocked Chimney Theory' Contemporary Education Dialogue, 5 (1) 7-27.
[13] Juneja, N. (2005). Exclusive Schools in Delhi, their land and the law. Economic and Political Weekly, XL (33), 3685-3690.

[14] Juneja, N. (2011). The right of the poor to education in private schools: Lessons from metropolitan experiences and need for proactive socil policy support. In Y. Singh, Schooling, statification and inclusion:some relections on the sociology of education in India (p. 278). New Delhi: National Council for Educational Research and Training (NCERT).

[15] Comptroller and Auditor General of India (CAG). (2005). Report No. 4 of 2005 (Civil) Autonomous Bodies, Delhi Development Authority, 4.1 Allotment of Land to Educational Institutions.www.cag.nic.in/reports/civil/ 2005_4/Chapter4.pdf (25, October 2006)

[16] Bhatnagar, D., \& Omer, K. (2005). Public utility of private schools: a study of eighty private schools of India . (mimeo).

[17] Juneja, Nalini (2014) India's New Mandate against Economic Apartheid in Schools Journal of International Cooperation in Education, 16 (2): 55-70. 